$<$ 原 著 $>$

アヒル B 型肝炎ウイルスの免疫組織学的研究

一フ化当日及びフ化 7 日目ウイルス接種アヒルに和ける肝内

DHBV の広がりと壊死, 炎症性細胞の進展の関連一

$\begin{array}{lrllll}\text { 福田 } & \text { 亮 } & \text { 高下 } & \text { 成明 } & \text { 沖永 } & \text { 聡 } \\ \text { 赤木 } & \text { 収二 } & \text { 小高 } & \text { 光宣 } \\ \text { 直美 } & \text { 島田 } & \text { 宜浩* } & & \end{array}$

要 旨：フヒルB 型肝炎ウイルス (DHBV)の急性感染における肝内ウイルスの広がりと肝細 胞の壊死, 炎症反応の関連を組織レベルで経時的に観察する目的で, 日本産アヒル20羽にフ化 7 日目に DHBV を接種し， 1 週每に 4 回採取した肝蔵につきDHBVs 抗体を用いた免疫染色 を行い, 肝内 DHBV の広がりと肝炎反応の部位を経時的に観察した. DHBVs 抗原は接種後 1 週目に全小葉の $50 \%$ の肝細胞飞現れ，以後 $70 ， 90 ， 80 \%$ と推移した。出現部位，消退部位とも 特異性はなく，全小葉でび漫性に観察された。肝炎反応は 1 週目より観察されたが，その壊死 部。細胞浸潤部とも散在性で, DHBVs 抗原存在部位之関連は認められなかった。血中 DHBVDNA 值は DHBVs 抗原の染色性と関連が見られ，DHBVs 抗原の肝内分布に反し，1週目を ピークに漸減した。

㮂引用語： DHBV DHBVs抗体 DHBV-DNA

\section{緒 言}

我々は既に HBV と同し hepadnavirus に属する】 ヒル B 型肝炎ウイルス $(\mathrm{DHBV})^{\prime)}$ 用いた感染実験 を行い, DHBVが HBV と類似した感染様式, 肝病变 を持つことを報告し，特にフ化7日目以降での感染は 殆ど一過性感染に終わる急性感染であり，HBV の急 性肝炎に類似することを明放比してきだ2

$\mathrm{B}$ 型肝炎の発症機序に関しては, 急性肝炎, 慢性肝 炎ともB 型肝炎ウイルス (HBV)の構成蛋白に対する

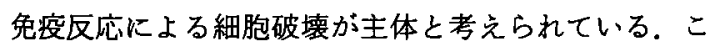
の際に浸潤細胞が直接ウイルス陽性細胞を破壊するこ とが示唆されてきており, 肝内浸潤りンハ球のサブ セットの解析が盛んK行われている.

今回我々は, DHBV 感染で見られる壊死, 炎症反応 とウイルス抗原の時相的，部位的関係を明らかにする 目的で, DHBV 粒子に対する抗体を作製し，これを用 いてフ化当日及びフ化7日目にDHBVを接種した ヒルに淤るウイルスの肝内の消長を免疫組織学的に 観察し, ウイルス抗原と壊死, 炎症反応の出現部位及

* 島根医科大学第 2 内科

〈受付日1988年12月16日>
びその進展部位の関連を比較し, DHBV 感染での肝资 反応のウイルス消退における意義について検討を加え た。

\section{DHBV の感染実験}

\section{材料と方法}

フ化 1 日齢及び 7 日齢の日本産フヒル（ホワイトよ゚ キン）各20羽に台湾産ホワイトペキンアヒルより得た DHBV 陽性血清 $25 \mu l$ を接種し， 1 週毎に 1 カ月にわ たり 5 羽す゚つ心臓採血を行い血清と肝蔵を採取した。 血清はウイルスDNAの検出に用い，肝臓は病理組織 学的観察及び，免度組織学的観察に用いた。

\section{2. ウイルス学的検討}

血中DHBV·DNAを既報のごとく spot hybridizationを用いて検出し ${ }^{2)}$, 標準 DNA と比較して半定量 した.

\section{3. 抗 $\mathrm{DHBV}$ 抗体の作製}

Marion らの方法に準じて血中よりDHBVs 抗原粒 子を精製し ${ }^{5}$, Freund の完全 adjuvand と共にモル モットに免疫して抗血清を得た。抗血清は非感染アヒ ルの血清蛋白を膠着させたアフィニテイカラムを通し た後濃縮し, 抗 DHBVs 抗体とした。

4. 抗 DHBVs 抗体を用いた免疫染色 


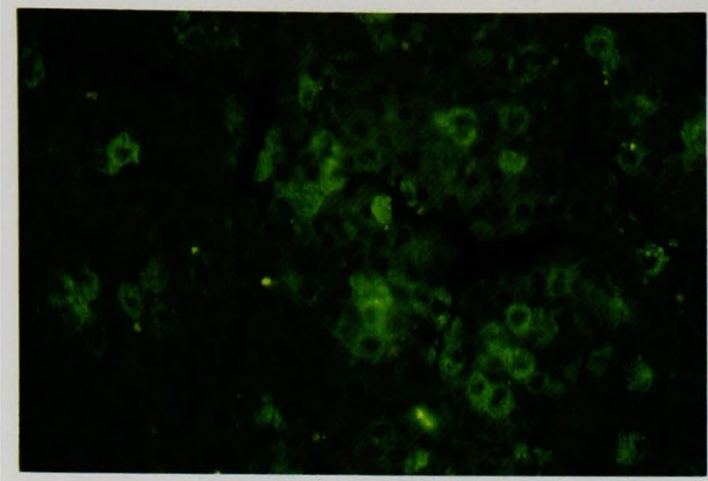

Fig. 1A DHBVs Ag was stained with valuable intensity in the cytoplasma of hepatocytes of a DHBV-infected duck. (7 day posthatch inocula-

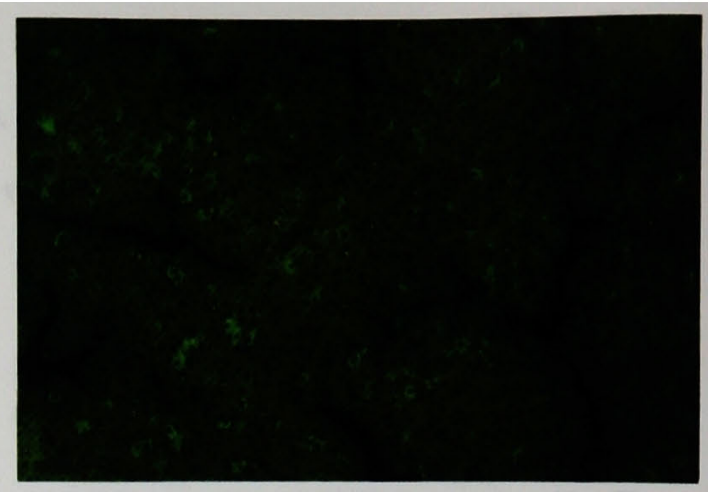

Fig. 1B DHBVs Ag Grade 2. DHBVs Ag was seen deffusely in the lobules. $\times 200$

tion, killed at 2 weeks postinoculation) $\times 400$

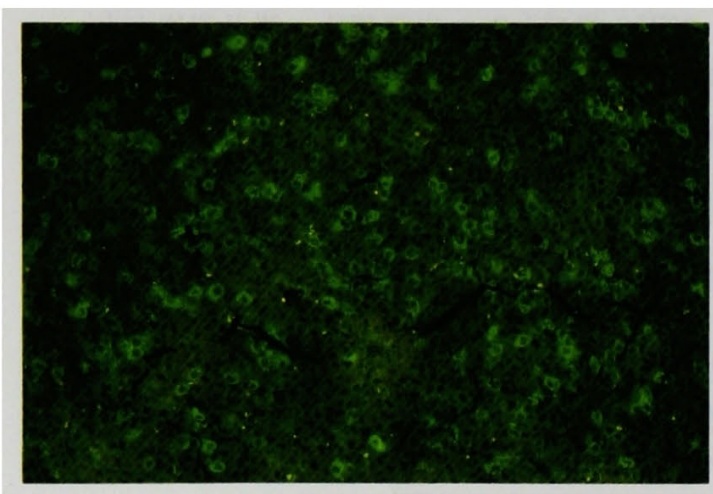

Fig. 1C DHBVs Ag Grade 3. DHBVs Ag positive hepatocytes increased in number. The distribution pattern of DHBVs $\mathrm{Ag}$ was diffuse and there was no specific localization of DHBVs Ag in the liver lobules. $\times 200$

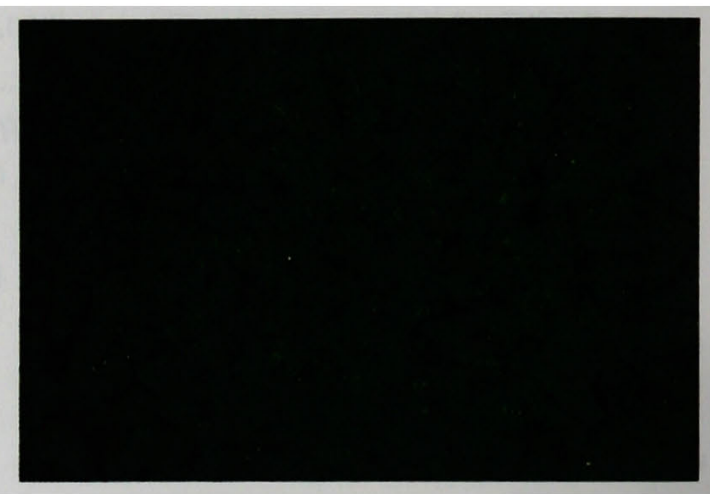

Fig. 1D DHBVs Ag Grade 5. DHBVs Ag was seen in almost all the hepatocytes. The intensity of staining became weak in comparison with those in Grade 2, 3. $\times 200$

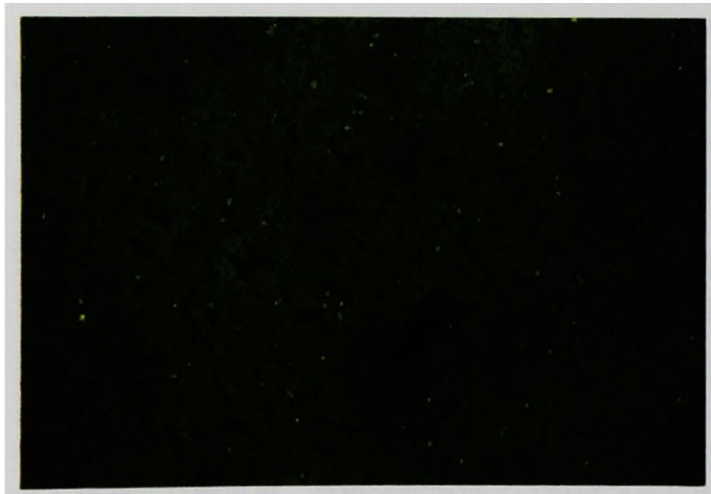

Fig. 1E The liver of a duck without inoculation of DHBV showed no DHBVs Ag in the liver. The liver was stained with DHBVs $A b$ as the first antibody. $\times 200$

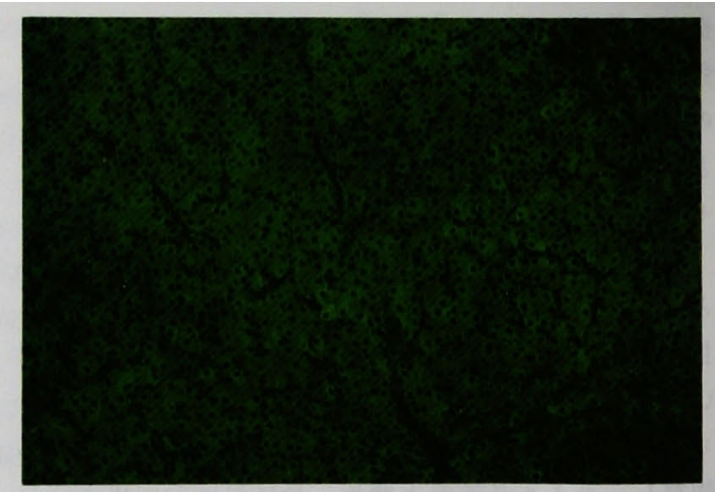

Fig. 1F DHBVs Ag Grade 4. The liver of a duck inoculated with DHBV on 7 day posthatch shows decrease in the intensity of the staining and in the number of hepatocyte with DHBVs Ag. $\times 200$ 




Fig. 2 DHBV-DNA in serum of ducks with transient and presistent infection of DHBV. DHBVDNA in the ducks inoculated with $\mathrm{DHBV}$ on 7 day posthach decreasd gradually with the observation periods whereas DHBV-DNA in those inoculated with $\mathrm{DHBV}$ on the day of patch showed relatively stable lebels. Data were showen as mean $\pm \mathrm{SD}$.

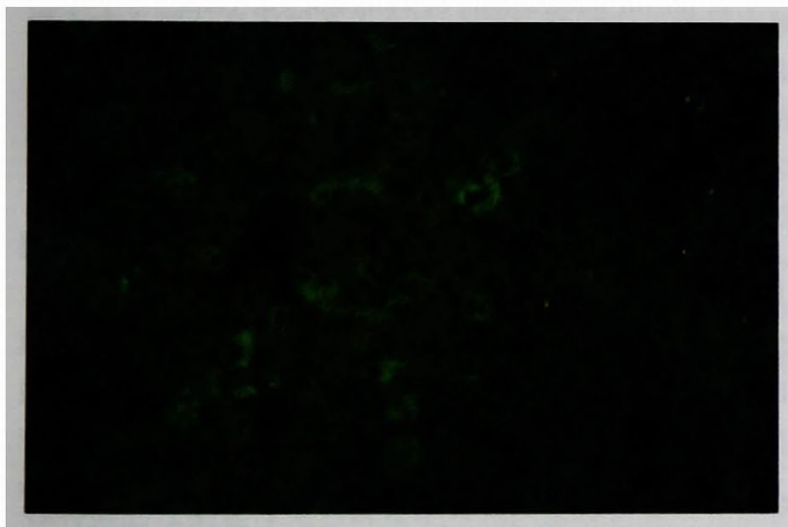

Fig. 3A The liver of a duck inoculated with DHBV on 7 day posthatch and killed at 2 weeks after inoculation. A focal necrosis and inflammatory cells infiltrated in a portal area were seen. $X$ 400

剖検時に作製した凍結肝組織を薄切後，1次抗体と して抗 DHBVs 抗体をPBSで400倍に希积し37度で 1 時間反応後, FITCラペルした抗モルモット・ヤギ IgG 200倍希釈して 2 次抗体とし,37度で 1 時間反応 させる間接蛍光抗体法を用いた。対照として非感染て ヒル 5 羽の肝缄を用いて同様の染色を行らととすに,

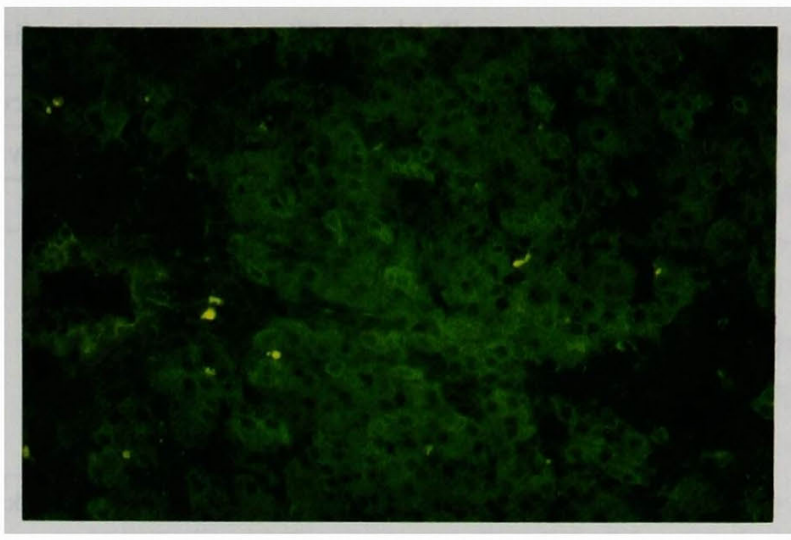

Fig. 3B Dense infiltrations of inflammatory cells in portal areas and some focal necroses were seen in the liver of a duck inoculated with $\mathrm{DHBV}$ on 7 day posthatch. The majority of DHBVs Ag positive hepatocytes were not asssociated to the necroses and inflammatory cells. $\times 400$

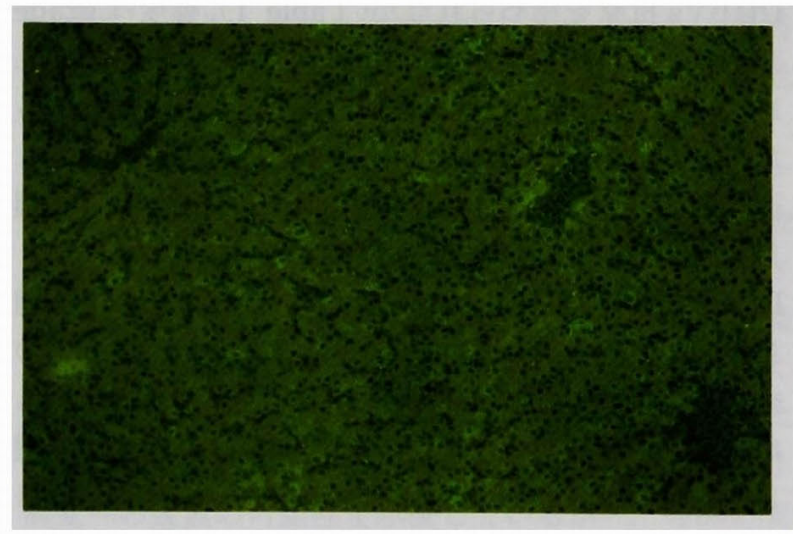

Fig. 3C The intensity of staining of DHBVs Ag was very weak and hepatocytes with DHBVs Ag decreased in number. Inflammatory cells were seen in portal tracts. (4weeks after inoculation of $\mathrm{DHBV}) \times 200$

一次抗体にノーマルのモルモットの血清を用いて非特 異的反応をチェックした。

\section{結果}

\section{1. 肝内 DHBVs 抗原の推移}

DHBVs 抗原は細胞質にび漫性に観察され，核内に は認められなかった（Fig. 1A). また, 膜型, 封入体 型等の染色様式は認められなかった。

倍率 4 百倍にて肝切片を観察し，個々のてヒルにつ いて任意の 3 視野での肝細胞100個における DHBV 陽性細胞数の平均を下記のごとく分類した：grade 
Table 1 Time course of the distributions of DHBVs Ag in the liver.

\begin{tabular}{c|c|c|c|c|c|c|c|c}
\hline \multirow{2}{*}{\begin{tabular}{c} 
Grade of distribution $\begin{array}{c}\text { of } \\
\text { of } \\
\text { DHBV Ag }\end{array}$ \\
\cline { 2 - 9 }
\end{tabular}} & \multicolumn{4}{c}{ Observation period (weeks post inoculation) } \\
\cline { 2 - 9 }$n$ & 1 & 2 & 3 & 4 & 1 & 2 & 3 & 4 \\
\hline 0 & 0 & 1 & 1 & 0 & 0 & 0 & 0 & 0 \\
1 & 0 & 0 & 0 & 0 & 0 & 0 & 0 & 0 \\
2 & 1 & 0 & 0 & 0 & 0 & 0 & 0 & 0 \\
3 & 3 & 1 & 0 & 2 & 4 & 0 & 0 & 0 \\
4 & 1 & 3 & 0 & 3 & 1 & 2 & 0 & 0 \\
5 & 0 & 0 & 4 & 0 & 0 & 3 & 5 & 5 \\
\hline
\end{tabular}

Data were shown as number of ducks.

$0 ；$ DHBV 陽性細胞なし，grade 1；1 以上20末満, grade $2: 21$ 以上 40 未満, grade $3 ; 41$ 以上 60 末満, grade $4 ; 61$ 以上 80 未満, grade $5 ; 81$ 以上.

DHBV 陽性細胞数の推移に関しては, 7 日目ウイル ス接種アヒルでは，接種後 1 週目で全例に肝内に DHBVs 抗原を認められたが(Table 1)，程度は grade 3が中心で比較的陰性細胞が多く観察された（Fig 1B). 接種後 2 週目では 1 例は DHBV 抗原陰性であっ たが，他は 1 例が Grade 3，残りの 3 例は grade 4で 1 週目に比し広い分布を示した（Fig. 1C). 接種後 3 週 目では 1 例に抗原陰性をみた他は全例 grade 5で, DHBV 陽性細胞数はピークを示した(Fig. 1D)。 4 週 目は陽性細胞は減少し，grade 3，4を示した。個々の 細胞の染色性は接種後 1 週目が最も強く, 経過之とも に漸減が見られた，フ化当日接種群では，接種後 3 週 目まではほぼ 7 日齢接種群と同じであったが，4 週目 でも全例が grade 5で, DHBV 抗原陽性細胞の漸減は 見られなかった。非感染てヒル肝及び，1次抗体にノー マルのモル毛ット血清を用いた対照試験は全て陰性で あった (Fig. 1E).

DHBV 陽性細胞の分布部位の経時的観察では, フ化 当日接種， 7 日目接種群とも，1週目より全小葉に散 在性に出現したが，出現部位には門脈周囲性，中心静 脈周囲性中，部分的集ぞく性等の特異性は見られな かった. Gradeの進行と共に陽性細胞は散在性からび 漫性に移行したが，やはり分布部位に特異性は認めら れなかった。 7 日目接種群では 4 週目に陽性細胞の潮 減が観察されたが，陰性化も全小葉で同程度に観察さ れ，DHBVs 抗原の消失過程においても部位別な特異 性は無く, 門脈周囲に残存する傾向も認められなかっ た (Fig. 1F).

\section{2. 血中 DHBV-DNA と肝内 DHBV 抗原の関連}

Table 2 Relationship between hepatic inflammations and the time after inoculation of DHBV

\begin{tabular}{c|c|c|c|c}
\hline \multirow{2}{*}{$\begin{array}{c}\text { Observation period } \\
\text { weeks postinoculation) }\end{array}$} & \multicolumn{2}{|c|}{$\begin{array}{c}7 \text { day } \\
\text { incolated ducks }\end{array}$} & \multicolumn{2}{c}{$\begin{array}{c}\text { one day } \\
\text { inoculated ducks }\end{array}$} \\
\cline { 2 - 5 } & P.I & F.N & P.I & F.N \\
\hline 1 & $2 / 5$ & $0 / 5$ & $0 / 5$ & $0 / 5$ \\
2 & $5 / 5$ & $4 / 5$ & $1 / 5^{*}$ & $0 / 5$ \\
3 & $5 / 5$ & $5 / 5$ & $0 / 5$ & $0 / 5$ \\
4 & $5 / 5$ & $2 / 5$ & $1 / 5^{*}$ & $0 / 5$ \\
\hline
\end{tabular}

Data were shown as number of ducks.

P.I : portal infiltrations of mononuclear cells. F.N : focal necrosis in the parenchyma.

* : activity was not significant.

7 日目接種群では血中 DHBV-DNA は接種後 1 週 目では 5 例全例に陽性で，以後 2 週目 4 例， 3 週目 3 例， 4 週目 3 例に陽性であった。血中ウイルス DNA 值 は 1 週目に最高値を示し，以後は漸减した。特に接種 後 2 週目から 3 週目にかけての DNA の減少が著明で 西った（Fig. 2)。肝内 DHBVs 抗原陰性例では血中 DHBV-DNA は陰性であったが，接種後 3 週目の 1 例， 4 週目 2 例の血中の DHBV-DNA 陰性例では DHBVs 抗原は非常に弱く染色され，血中 DHBV. DNA とDHBVs 抗原の染色性の間には関連が見られ た。 フ化当日接種群でも血中 DNA の漸减傾向は認め られたが，7日目接種群に比し殆ど横ばい傾向を示し た。

\section{DHBVs 抗原と肝炎反応}

7 日目接種群では, 1 週目にDHBVs 抗原は全例散 在性に出現したが，この時期は 2 羽に門脈域への軽度 の細胞浸潤が見られた（Table 2)，2 週目にはほぼ全 例に門脈域の細胞浸潤が見られ，実質内に巣状壊死の 
散在が加わったが, DHBVs 抗原はび漫性で, 巣状壊死 が散在性であるのと対照的であった（Fig. 3A)．3 週 目では門脈域の細胞浸潤，巣状壊死とも増強傾向が見 られたが，個々の DHBVs 抗原陽性細胞に浸潤細胞が 接触する像は認められなかった(Fi. 3B)，4週目では 巣状壊死はほぼ消失し, 門脈域の細胞浸潤も減少が見 られた。この時もDHBVs抗原はび漫性に消退し，抗 原消失部に炎症細胞が集積する像は無かった。フ化当 日接種群では有意の肝炎反応は認められなかった (Fig. 3C)

\section{考 察}

HBVの感染様式に宿主の免疫状態が密接に関係す ることは周知である。我々は既に DHBV の感染様式 む宿主の免疫状態と関連することを明らかにしてき た。特に肝炎反応はウイルス血症の消失と関連が見ら れる.この肝炎反応は，種々の免度調節剤を用いた聿 験よりフヒルの免疫状態と深い関連を持つことから， DHBV 感染でも肝炎はウイルスの排除と関連すると 推測されている6).

肝炎は宿主の免疫反応と考えられ，特に慢性活動性 肝炎ではキラーT 細胞によるウイルス陽性細胞の破 壊とする説が有力であるが7), HBV 感染では接種実験 によりウイルスの肝内での広がりと浸潤細胞の関連を 経時的に観察することは困難である. 今回 HBV と同 族のDHBVを用いて，フ化当日及びフ化 7 日目に DHBV を接種したてヒルを用いて比較的初期よりウ イルスの広がりと壊死, 炎症反応との関連を組織レべ ルで観察し得たが，既報のごとくフ化当日のウイルス 接種では有意の肝炎反応は見られなかった，HBVで の急性肝炎に相当するフ化 7 日目ウイルス接種では, 肝内ウイルスの広がりと壊死, 炎症反応の部位の間に は特異的な関連は見られなかった。急性肝炎の発症機 序は抗体，補体系の関連が推測されるものの，やはり キラーT 細胞の関与が強いとする報告を考えると， DHBV 感染での壊死，細胞浸潤と，そのターゲットと しての DHBVs 抗原の関連性は弱いと考光られる。今 回はDHBVs 抗原のみを用いており，DHBVc 抗原等 の他の抗原に関しては未検討であるが，ウイルスが感 染, 複製する細胞内では必然的にDHBVc 抗原む産生 されていると考えられ，この抗原に関しても同様の推 測が成り立つ.しかし，この事はDHBV の急性感染に 宿主の免疫が関与する可能性を否定するるのでは無 い. 同様の所見は HBV の急性肝炎に括いても報告さ れており ${ }^{8)}$, 両ウイルスはこの点で類似している. 更
に，我々も cyclophosphamide を投与したアヒルを用 いての急性感染実験からも，DHBV の急性感染には宿 主の免疫反応が関与することを認めている4. ただ，ウ イルス抗原が消失する際も，細胞内に减弱した蛍光が 残ることからも，少なくとも急性感染に於いては，ウ イルスの排除に肝細胞破壊以外のものが推測される.

DHBV の接種実験での免度組織学的観察では, 血中 DHBV の出現が接種後 4 7 7 日目とされる一方, 肝内 でのDHBV抗原は接種後 2 日目頃とされてい $ろ^{9 \sim 11)}$.この事は接種後血中に検出されるウイルスは， 一旦肝細胞内で增殖したものと考えられる。この血中 ウイルス DNA が肝内 DHBV 抗原陽性細胞の増加に 反して潮减するのは，感染初期に大量のウイルスが産 生されることを意味するのか，ウイルスがある程度広 がると増殖が弱まることを意味するのかは不明である が、ある種のフィードハッックによるウイルス側の要因 か,インターフェロン等の宿主側の要因が推測される. DHBV の消失も細胞性免疫反応以外にこれらの要因 が関与する可能性がある．今後はこれらの因子を想定 したより機能的な面からの検討が必要と考えられる.

DHBV の慢性感染では，既に報告したごとく，ホワ イトペキン種では $3 ー 4$ 歳齢のキャリフーでは門脈域 の弱い細胞浸潤を示するのが散見されるが，有意の肝 炎を持つるのは見られていない12)。これらの免疫組織 学的検索でもDHBV 抗原と壊死部の関連は見られて いない.Jilbert らはフ化当日接種でもDHBVs 抗原は 9 日目には門脈域に染をりやすいと報告して進行性肝 病変への進展の可能性を示唆しているが'13)，今回の実 験ではこの所見は見られなかった。しかし，一方で DHBV と関連した進行性肝病变が報告され ${ }^{14,15)}$, DHBV 抗原の部分的集ぞく像を見るとする報告 ${ }^{16)}$ ，さ らにはアヒルの種差による肝病変の差異とする報告も あり ${ }^{17)}$, 慢性感染に関してはフヒル種の差や,ウイルス のサブタイブを含め，更に検討を要すると思われる．

感染様式や宿主の反応飞関して DHBV と HBVを 同一レベルで論ずるまでには解明すべき点は多いか， ウイルスの増殖面ではかなりの類似性があり ${ }^{18)}$ ，更に 我々も非特異的抗原を用いた赤血球凝集反応や plaque forming assayによるアヒルの免疫に関する 実験上りDHBV の感染様式にも HBV 同様, 免度反 応が強く関与することを認めている(未発表成績)。今 後 DHBV を用いて，各種抗原の肝細胞での局在を電 顕レベルで観察するとともに，その肝炎に於ける浸潤 細胞の意味，壊死の原因をより機能的に捉える実験を 
行らことで，間接的にではあるが HBV の感染様式や その病原性を検討することが可能ではないかと考え る.

本論文の要旨の一部は第59回日本内科学会中国・四国合 同地方会にて発表した。

\section{文 献}

1) Mason WS, Seal G, Summers J: Virus of Pekin duck with structural and biological relatedness to human hepatitis $B$ virus. $J$ Viol $36: 829-836,1980$

2）福田 亮：フヒル B 型肝炎ウイルス感染一感染 様式と病原性におけるヒト B 型肝炎ウイルスと の比較. 肝缄 $28: 1-8,1987$

3）福田 亮, 赤木収二, 沖永 聡, 他：フヒル B 型 肝炎ウイルスの感染様式に及ぼすステロイド昘の 影響. 肝缄 $29: 168-172,1988$

4）福田 亮, 沖永 聡, 赤木収二, 他：フヒル B 型 肝炎ウイルス感染での viremia の推移に及ぼすス テロイド阂と cyclophosphamideの影響. 肝缄 $29: 9-14,1988$

5) Marion PL, Kight SS, Fettelson MA, et al : Major polypeptide of duck hepatitis $B$ surface antigen particles. J Virol $48: 534-541,1983$

6) Fukuda R, Okinaga S, Akagi S, et al: Alteration of infection pattern of duck hapatitis $B$ virus by immunomodulatory drugs. J Med Virol $26,387-396,1988$

7) Dudley FJ, Fox RA, Sharlock S: Cellular immunity and hepatitis-associated, Australia antigen liver disease. Lancet 1: 723-726, 1972

8）谷川久一, 佐田通夫：肝微細構造からみた急性 B 型肝炎の発症機序の検討.「第15回犬山シンポシウ ム,ウイルス肝炎のトビックス」犬山シンボシウム 記録刊行会編, 中外医学社, 東京, 1988, p236-244

9) Halpern MS, England JM, Flores L, et al : Individual cells in tissues of DHBV-infected ducks express antigens crossreactive with those on virus surface antigen particles and immature viral cores. Virology $137: 408-413,1984$
10) Halpern MS, McMahon SB, Mason WS, et al: Viral antigen expression in the pancreas of DHBV-infected embryos and young ducks. Virology 150:276-282, 1986

11）横須賀収，小俣政男，伊藤よしみ，他：Pre-S1/S2， core抗原ボリベブタイドの肝内に拈ける発現に ついてーDHBV 感染実験での経時的検討一. 肝蒍 $29: 13-17,1988$

12) Uchida T, Suzuki K, Arii M, et al : Geographical pathology of duck liver infected with duck hepatitis B virus from Chiba and Shimane in Japan and Shanghai in China. Cancer Research 48: $1319-1325,1988$

13) Jilbert AR, Freiman JS, Burrell CJ, et al: Early virus cellinteractions in duck hapatitis B virus infection: A time-coures study of tissue tropism and state of virus production. In : Viral hapatitis and liver disease. Edited by Zuckermann AJ. Alan R, Liss, Inc. New York, 1988, p497-500

14) Omata $M$, Uchiumi $K$, Ito $Y$, et al : Duck hepatitis $B$ virus and liver diseases. Gestroenterology $85: 260-267,1983$

15) Marion PL, Kight SS, Ho BK, et al: Liver disease associated with duck hepatitis $B$ virus infection of domestic ducks. Proc. Natl. Acad. Sci. USA 81 : 898-902, 1984

16）伊藤よしみ，田川まさみ，内海勝夫，他：急性及び 慢性 DHBV 感染症におけるウイルスDNA, mRNA 及び抗原の采統的発現に関する研究。日消 病会誌 $85: 1376-1380,1988$

17) Omata M, Zhou $Y Z$, Uchiumi $K$, et al : Hepatitis $B$ virus DNA, antigen, and liver pathology in ducks: An animal model of human liver disease. In : Hepadna Viruses, edited by Robinson W, Koike, K, Will H. Alann R. Liss, Inc, New York, 1987, p349-356

18) Summers J, Mason WS: Replication of the genome of a hepatitis B virus-like virus by revers transcription of an intermediate. Cell 29 : 403-415, 1982 


\title{
Immunohistochemical study of Duck hepatitis B virus in acute infection: Relationship between the distribution of DHBVs $\mathrm{Ag}$ and the inflammatory changes in the liver
}

\author{
Ryo Fukuda, Naruaki KoHge, Satoshi OKInaga, Mitsunobu Hidaka, \\ Shuji AKagi, Naomi ONo and Yoshihiro ShIMAdA*
}

To investigate the relationship between the distribution of DHBVs Ag and the location of hepatic inflammations in the liver in acute infection of DHBV, 20 ducks were inoculated with DHBV on 7 day posthatch and sacrified weekly after the inoculation for one month. DHBVs Ag was detected in about $30,70,90$ and $80 \%$ of the hepatocytes at $1,2,3$ and 4 weeks after the inoculation, respectively. The distributions of DHBVs Ag were diffuse and there was no specificity in localization of the antigen throughout the observation period. Although focal necrosis and inflammatory cells in portal tracts were seen mainly 2 weeks after the inoculation, the distributions of these hepatic inflammations were spotty and there was no locational relations between DHBVs Ag and the inflammatory changes. There seemed to be another factors for elimination of the virus aside from immunological mechanism in acute infection of DHBV.

\footnotetext{
* Second Department of Internal Medicine, Shimane Medical University (Izumo)
} 